Chapter 18

\title{
Contribution of Vegetation to Alleviate Slope's Erosion and Acidity
}

\author{
Normaniza Osman, Mohammed Saifuddin and \\ Aimee Halim
}

Additional information is available at the end of the chapter

http://dx.doi.org/10.5772/57228

\section{Introduction}

Most of the slope soils in the tropical region such as in Malaysia is arid and infertile due to lack of buffering capacity and low clay activities which resulted in soil acidity. In addition, high intensity rainfall and extreme conditions of slope such as transient drought and lack of nutrients have reduced the survival and growth of potential plants. Rain water percolation which leaches basic elements such as calcium, magnesium, potassium and sodium from the soil profile is also another factor which contributes to soil acidity.

Soil acidity has a huge negative impact on fertility, biological activities and plant productivity. Fortunately, the use of vegetation and their association with microbes have great potential to alleviate soil acidity and erosion problems. Moreover, heavy metal-tolerant plants also play an important role in phytoremediation. Therefore, proper plantation and management of plants in polluted and acidic soil may significantly contribute to restoring the natural environment.

The practice of using vegetation, so-called "Bio-engineering" technique, combines an ecological, mechanical and hydrological concept which has been successfully applied to alleviate soil erosion in Malaysia [1]. The combined right choices of plants and planting technique confer numerous advantages such as producing a high biodiversity, low cost-maintenance, selfsustainability as well as environmental friendly slope [1]. Nonetheless, the interaction of vegetation and soil are complex as it is involved with, inter alia, varying soil properties, soil pollutants and different type of plant coverage. Therefore, in light of fast developmental land transformation and climate change, it is of a great challenge to integrate all plant-soil properties and its interaction with the whole ecosystem and environment. 


\subsection{Objectives of the chapter}

This book chapter will explore the attributions of vegetation to alleviate the most common slope problems in Malaysia; acidity and erosion. This chapter will also provide potential characteristics of plants to reinforce soil and the mechanism of Aluminium (Al) accumulator plant to alleviate soil acidity. The specific aims of this book chapter are to:

a. Describe the ecological approach towards slope stabilization;

b. Outline the vegetation effects on erosion rate and carbon sequestration;

c. Elucidate the mechanism of $\mathrm{Al}$ accumulator plant to alleviate soil acidity and

d. Exhibit some potential slope plants.

\section{Ecological approaches to stabilize slope}

There are many types of natural and manmade slopes exist in Malaysia. Due to the nature of topography e.g. slope angle, length, aspect, gradient and curvature, and the weather conditions, these slopes become unstable and make serious geologic hazards. Around the world, landslide depends on the geological characteristics, hydrological condition and rainfall distribution [2,3]. In Malaysia, significant numbers of slope failure are reported on manmade and residual soil slopes especially at the time of high intensity rainfall due to rapid change of soil properties, particularly physical properties, such as bulk density, cohesiveness and shear strength [4]. However, there are three common triggering factors for slope failure in respect to Malaysia which are intense rainfall, water level change and change of slope loading (Figure 1), indicating hydrological condition gives infavorable impact on the slope stability. Apart from that, landslides also occurred due to the human activities such as cultivation, excavation for housing, foot paths and deforestation or construction works in hillsides and lack of plantation in hilly area [5,6]. In addition, improper slope design might cause manmade slope failure which has been acknowledged as one of the most reasons for frequent disaster around the world [7]. To overcome this problem, the slopes need to be proper designed, considering the geological characteristics, structural model, local weather and soil characteristics [8]. From eco-physiological point of view, the plant availability, so-called bioengineering systems, has become an alternative solution to minimize the impacts and stabilize the slope $[1,9]$.

Bioengineering systems are extremely beneficial as it incorporates with geotechnical engineering, ecological and biological aspects $[7,11]$. In bioengineering techniques, less heavy equipments and live plants are usually used which are cost effective and provided long-term soil stability [12]. Generally, newly cut and manmade slope soils are unstable and expose to soil loss. Hence, it is needed to be made more resistant to erosion. In our study, Nordin et. al. [13], have discovered that different composition of root distribution and branching between two potential slope plants, namely; Acacia mangium and Leucaena leucocephala (Table 1) caused the differences in pull-out values. In tandem with L. leucocephala's ability to establish on slope's harsh condition and reinforced the soil [14], it exhibited the higher force of pull-out, thus, 


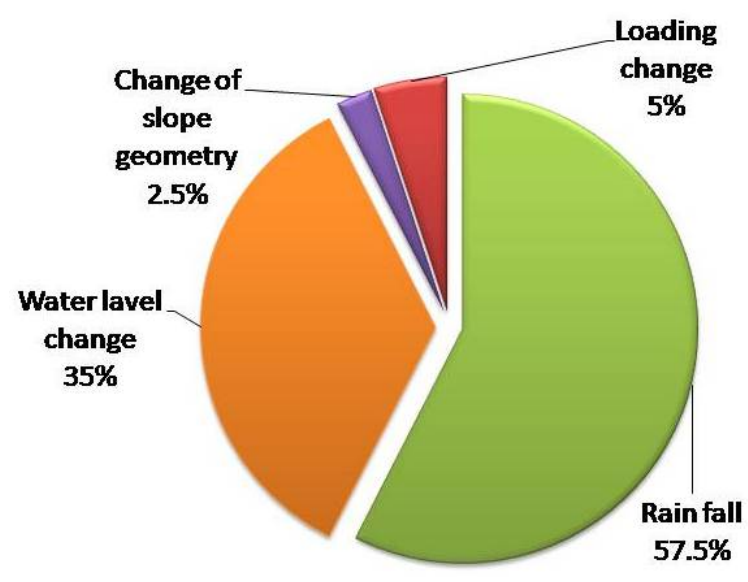

Figure 1. Common triggering factors which is related to slopes erosions [10].

showing its capability to resist the uprooting forces. This feature helps the species anchorage and resists the slope against forces such as wind. Interestingly, the study also found that the pull-out force is much affected by the tensile strength $(\mathrm{R}=0.88$; Figure 2$)$. The tensile strength decreased with increasing root diameter. Thus, this property of higher tensile strength in the finer roots would ultimately yield an increase in shear strength of the root-soil composite in the field and provide better ductility to the root-soil composite with a higher capacity to withstand surface erosion and runoff [15].

\begin{tabular}{lcc}
\hline \multicolumn{1}{c}{ Species } & Pull-out Force (KN) & Tensile strength (N/mm $\left.{ }^{2}\right)$ \\
\hline Acacia mangium & $1.69 \pm 0.34$ & $54.37 \pm 10.80$ \\
\hline Leucaena leucocephala & $2.25 \pm 0.45$ & $104.83 \pm 18.72$ \\
\hline
\end{tabular}

Significant difference between species at $\mathrm{LSD}_{\mathrm{p}<0.05}=0.73$ (pull-out) and 18.9 (tensile strength)

Table 1. Pull-out test and tensile strength of Acacia mangium and Leucaena leucocephala (data are means \pm standard error)

Knowing the importance of vegetation, however, the problem of vegetation establishment on freshly cut slope is a succession problem, in which naturally, the process takes a longer time. Fortunately, with the human helps and input, we can accelerate this process. Normaniza and Barakbah [1] proposed a concept for establishing vegetation cover on slopes which enhanced the process of natural succession (Figure 3). The introduction of pioneer species on slope is to initiate the succession process and later to accelerate the ecological restoration as a whole. Initially, the proposed pioneer species is to improve the quality of soil, be it acidic or infertile soil. 


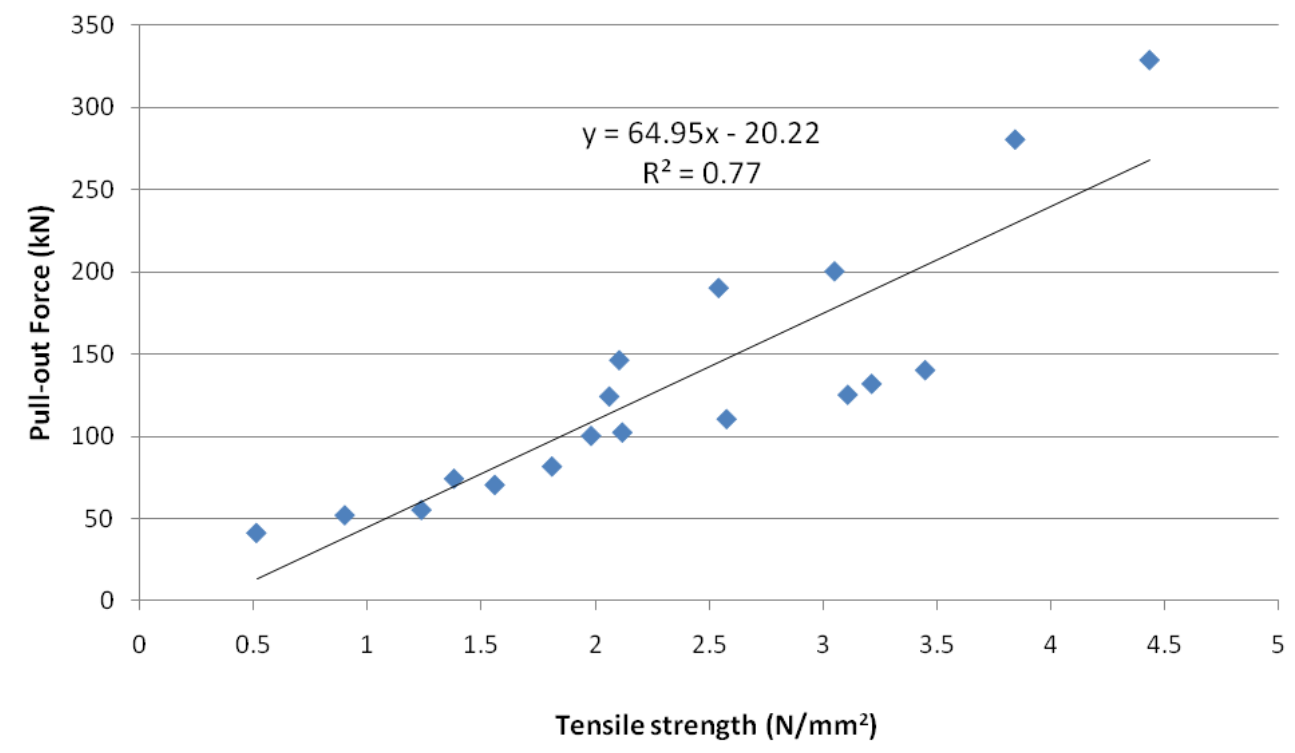

Figure 2. The relationship between pull-out force and root tensile strength [13].

In relation to the proposed concept, the selected pioneer must exhibit prominent characteristics which include high growth rate, good root profiles, water relations and high tolerance to a wide range of adverse factors with regard to soil quality, microclimate and mechanical stress $[9,16,17]$. It is anticipated that once the pioneer is established, the succession process would be enhanced through the changes of abiotic and biotic factors. Consequently, influx of other species will enrich the plant biodiversity of slopes. This plant community changes would not only hasten the process of natural succession but would also attract small animals such as insects and birds to the ecosystem. This fauna association would assist in promoting "florafauna" interaction via being the agents of seed dispersal, which would ultimately enhance the natural plant succession process.

This ecological approach towards slope stabilization has been proven on slope projects conducted by our team at several highways cut slopes in Malaysia [1,18] (Figure 4). Our study showed that legume trees which act as pioneers had increased the species diversity and slope stability parameters of the slope (Table 2). The legume tree plots exhibited higher root length density and resulted in a lower saturation level of the soil. In addition, penetration resistance was observed to increase with presence of legume trees. The increment of shear strength at 30 $\mathrm{cm}$ soil depth was prominent in legume tree plot. Overall increment of slope stability parameters indicated the positive effect of legume trees in reducing the probability slope failures, since most surface failures occur at a depth of 20-50 cm [1]. In contrast, the grasses plots had almost saturated, 83.9-93.2\%, a characteristic of failing slope. 


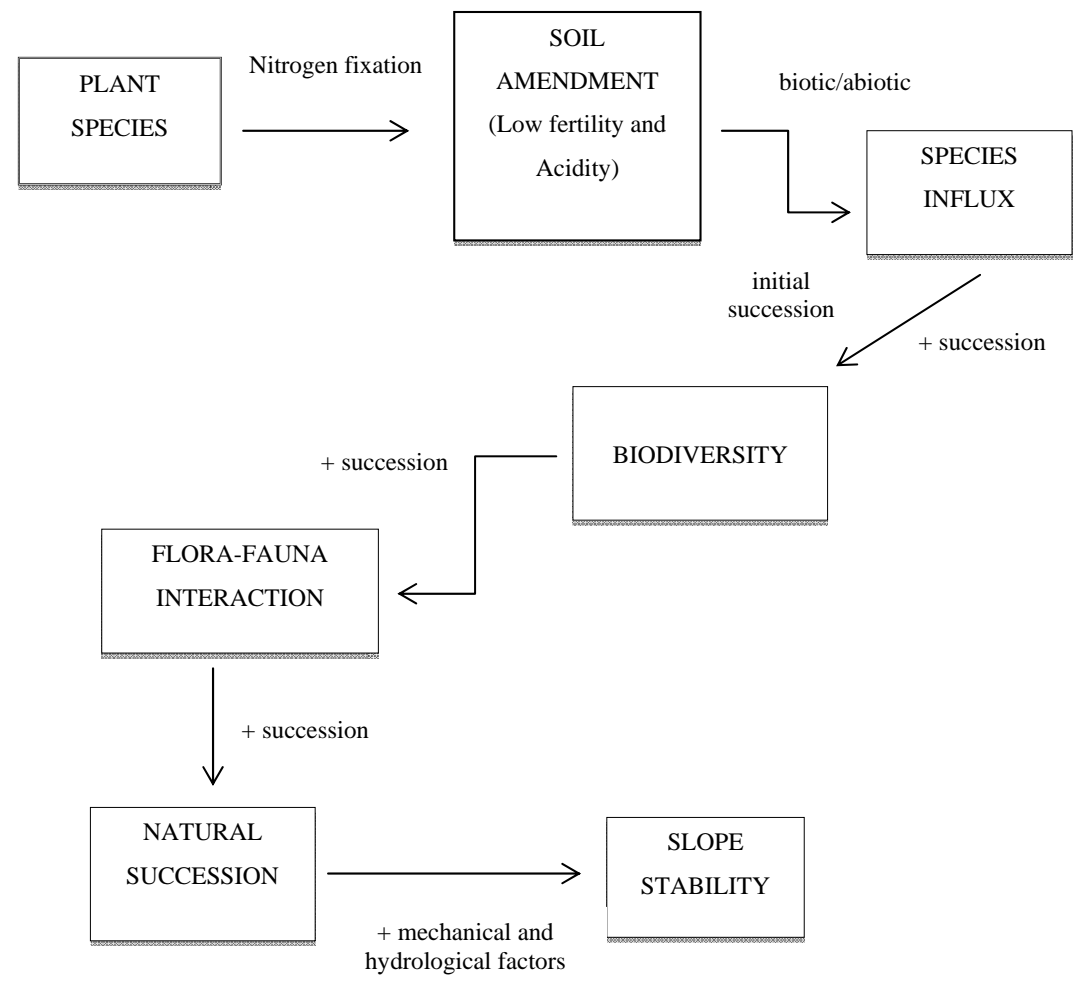

Figure 3. A proposed concept for establishing vegetation cover on slopes and enhancing the process of natural succession [1].

\begin{tabular}{lcc}
\hline \multicolumn{1}{c}{ Parameters } & Grasses & Legume trees \\
\hline Saturation level (\%) & $83.9-93.2$ & $73.6-81.2$ \\
\hline Root length density $\left(\mathrm{Km} \mathrm{m}^{-3}\right)$ & 0.86 & 9.4 \\
\hline Penetrability (24 months) (MPa) & $0.97-1.5$ & $1.44-2.01$ \\
\hline Shear strength (at 30 cm soil depth at 24 months) (KPa) & $100.5 \pm 5.5$ & $104.6 \pm 2.4$ \\
\hline
\end{tabular}

Table 2. Slope stability parameters between the plots (grasses and legume trees) 


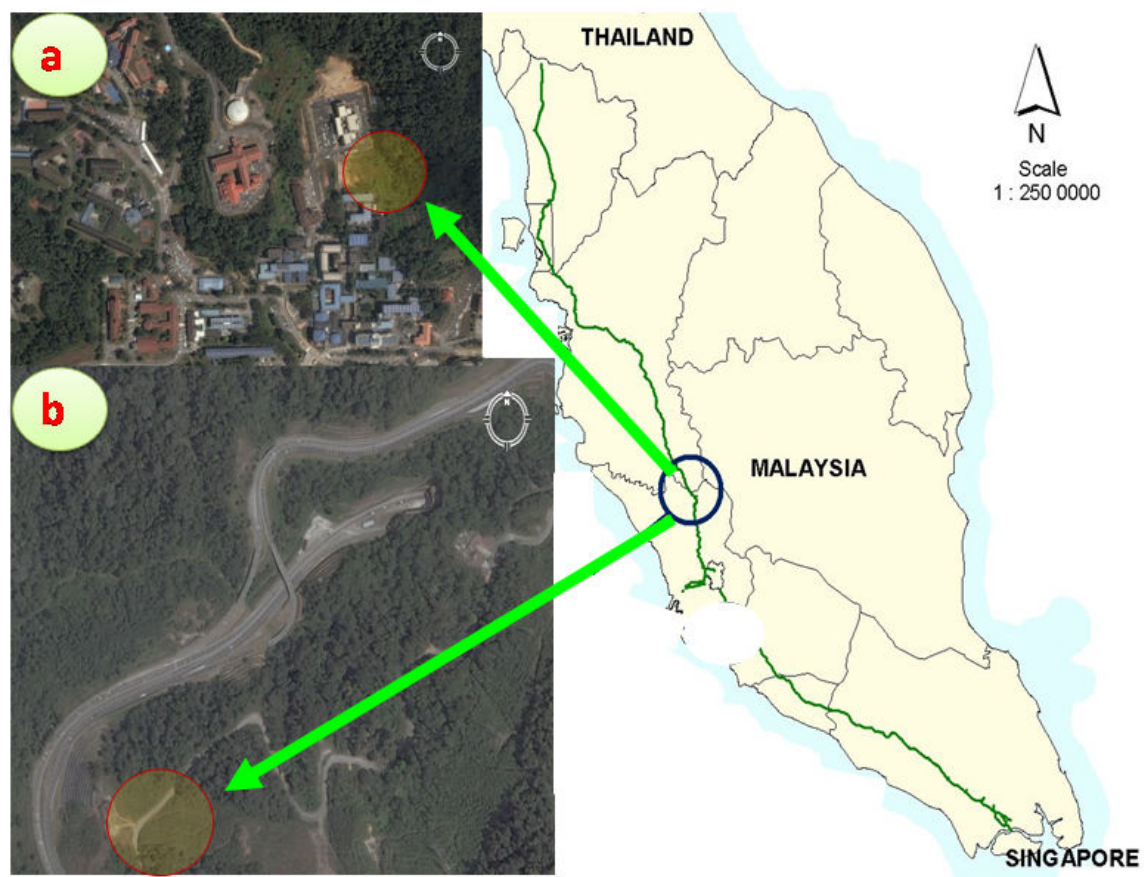

\section{Topographic map of surveyed slopes in Peninsular vene,}

Figure 4. Topographic map of surveyed slopes in Peninsular Malaysia; a) Faculty of Science, University of Malaya; latitude $03^{\circ} 07^{\prime} 28.5^{\prime \prime} \mathrm{N}$, longitude $101^{\circ} 39^{\prime} 14.6^{\prime \prime} \mathrm{E}$ and b) Batu 38, Pusat Pengajian Luar, University of Malaya, Ulu Gombak; latitude $03^{\circ} 20^{\prime} 45.27^{\prime \prime} \mathrm{N}$, longitude $101^{\circ} 46^{\prime} 26.52^{\prime \prime} \mathrm{E}$.

\section{Impacts of vegetation on soil erosion and carbon sequestration}

\subsection{Soil erosion}

The use of vegetation to control soil erosion has been practiced for many centuries, firstly introduced in China in 16th century to stabilize dam [19]. Nowadays, this practice of vegetation has been successfully applied to stabilize slope throughout the world. The vegetation and erosion process are interrelated by the ability of the plant life growing on soil and the interaction of root and soil [20]. But the interaction of vegetation and soil are complex as it involved with, inter alia, the combination of soil types, plant coverage and the steepness of slope. There are many factors also responsible for controlling soil erosion such as soil elements, soil density, slope length, existing plant species and plant position on slope, plant age, plant coverage and plant root distribution. Moreover, the revegetation process also influenced by the plant-soil interaction such as soil acidity, nutrient content, and drought conditions. Toriman and Shukor 
[21] found that in a forest area of Malaysia, interception reduces $23.9 \%$ of the total rainfall and it is varying subjected to plant canopy, density and types of plants.

In our research findings, the plant density treatment (i.e. low, medium and high densities) of the potential slope plant species, Melastoma malabathricum provided the significant findings on the interception process at the sloping areas. A higher plant density increased the leaf area index (LAI) (Figure 5) as well as contributed to a higher plant growth. In addition, the highest plant density in the studied plots recorded the lowest erosion rate, indicating that soil erosion was lower at the area with a higher vegetation density by intercepting rainfall by plant canopy (LAI) (Figure 6).

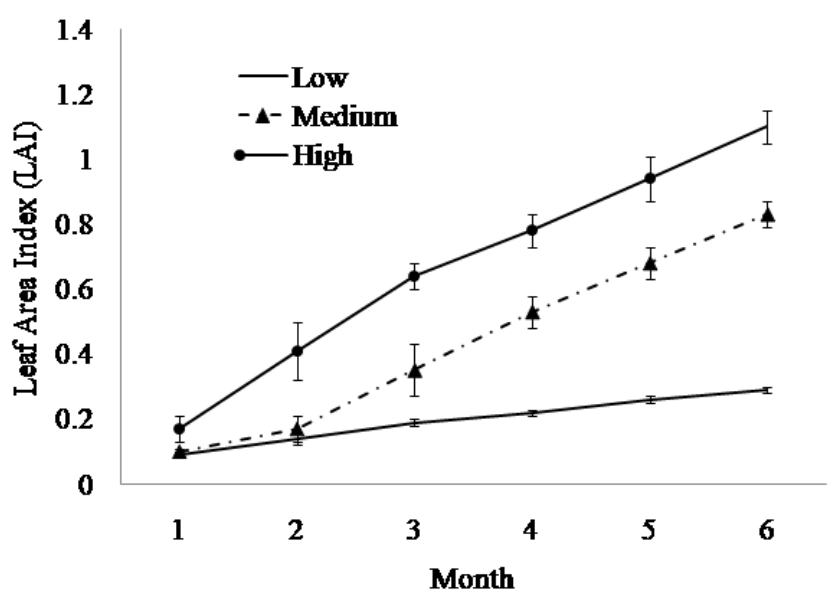

Figure 5. The Leaf Area Index (LAI) of M. malabathricum of three different density treatments.

Furthermore, the higher the plant density, the higher the soil carbon content is. This result also indicates that the increased of species density influenced in carbon cycle via storing the large amount of carbon in soil through photosynthesis and respiration. It can be explained by the large amount of litter fall on the soil surface, thus, enhanced the decomposition process which in turns, increased the organic matter and mineral content at the top layer of soil. Apart from that, the amount of soil carbon was directly related to the root length density (Figure 7). Higher soil carbon content was observed at the greater root length density (RLD) area, indicating the distribution of soil carbon was induced by the root distribution. The root system supplies decomposable organic matter in soil and supports a large microbial community in the rhizosphere [22,23], thus, help in distribution of soil carbon. In addition, a higher plant density produced more litter on the top layer of the soil surface, which in turns increased the decomposition process via carbon and nitrogen cycles [24], hence, increased the soil $\mathrm{pH}$ value as well. In aftermath, the soil $\mathrm{pH}$ was enhanced. 


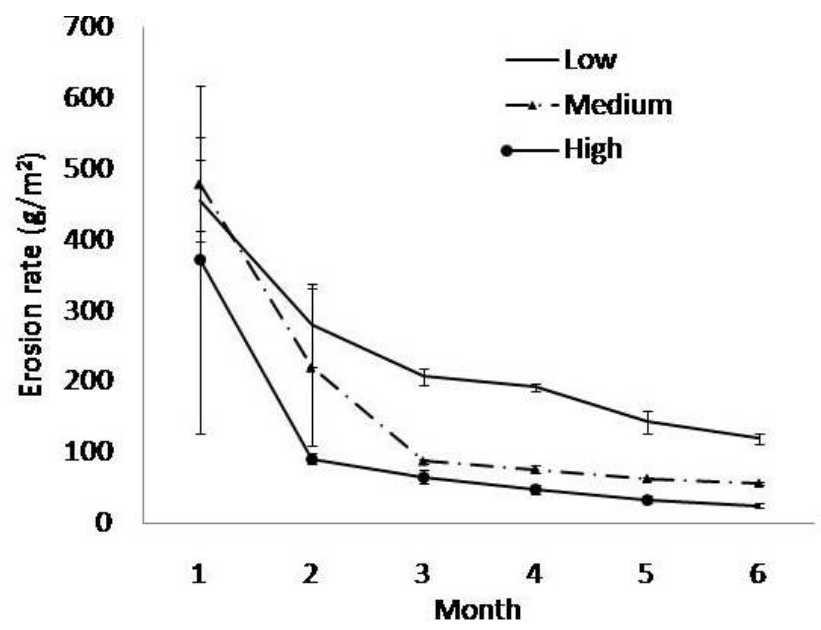

Figure 6. The erosion rate on slope at different plant density of M. malabathricum.
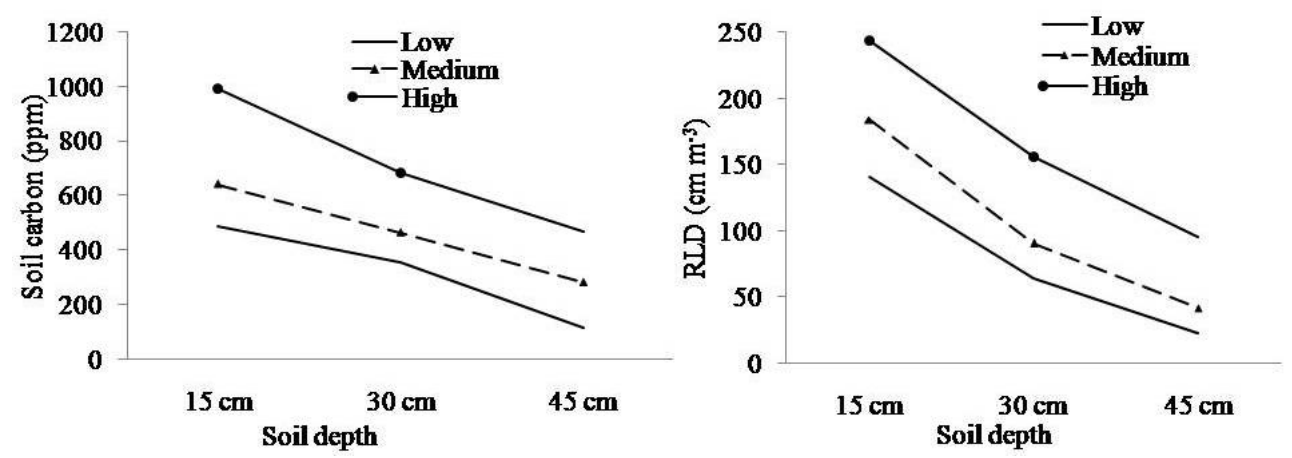

Figure 7. Soil carbon content and root length density (RLD) with depth of the species studied at different plant density.

\subsection{Carbon sequestration and carbon sink potentiality}

Carbon sequestration, a natural processes in ecosystems where $\mathrm{CO}_{2}$ is absorbed from the atmosphere and stored it in plants and soil. During the photosynthesis process, plants absorb $\mathrm{CO}_{2}$ and converted into carbohydrate or starch [25]. In this way, atmospheric carbon is stored in the leaves, stems, and roots for a long period of time (Figure 8). When a tree is utilized for wood, its ability to sequester carbon is extended, and the carbon is not released until the product burns or decomposes. Vegetation plays an important role in sequestrating carbon, as one way to alleviate global warming, a global issue discussed nowadays. Whereas, carbon sink potential is defined as a natural entity, process, activity 
or mechanism such as plants which can alleviate greenhouse gases from the atmosphere. It has been reported that forest, for example the tropical rainforest, is one of the largest carbon sinks in the world [26]. The higher the potential of the plant to absorb $\mathrm{CO}_{2}$, the greater is the capacity of the plant to be a carbon sink potential. The quantitative measure on the $\mathrm{CO}_{2}$ absorption by individual plant will assist to assess the carbon sink potentiality of plants. The plants which exhibited high photosynthetic components i.e. $A_{\max }$ $\mathrm{A}_{400}$, light and $\mathrm{CO}_{2}$ saturation levels, are the good carbon sink plants.

$\mathrm{A}_{\max }$ is an indicator of acclimatisation towards elevated $\mathrm{CO}_{2}$ and can be used to determine the plant growth capacity in a future climatic situation. In our study, Leucaena leucocephala, Peltophorum pterocarpum and Justicia betonica exhibited higher Maximum Assimilation Rate $\left(\mathrm{A}_{\max }\right)$ and Quantum Efficiency $(\mathrm{QE})$ than Lantana camara and Thunbergia erecta (Table 3). From the simulated $\mathrm{CO}_{2}$ experiments, L. leucocephala, P. pterocarpum and J. betonica seem to show the ability to utilize high concentrations of $\mathrm{CO}_{2}$ in order to enhance photosynthetic rate. Furthermore, in the simulated light experiments, no photo-oxidation occurs. It has been reported that plants which can maintain the use of captured light energy for NADPH and ATP synthesis, may provide more sink capacity. This ability, then, would diminish the accumulation of excitation energy in the photosynthetic pigments, which is a major cause of photo-oxidative damage. Thus, the capacity to resist photo-oxidation is an indication that L. leucocephala, $P$. pterocarpum and J. betonica are the good potential carbon sink species. In addition, L. leucocephala and $P$. pterocarpum remain photosynthetically comparatively active at lower $\mathrm{CO}_{2}$ concentrations, indicating low $\mathrm{CO}_{2}$ is required to initiate the photosynthesis process of $L$. leucocephala and P. pterocarpum. Changes in $\mathrm{CO}_{2}$ concentrations affected the photosynthesis of both species similarly; L. leucocephala and P. pterocarpum seemed to show higher ability to utilize high concentration of $\mathrm{CO}_{2}$ in order to enhance photosynthetic rate as compared to other species studied. As inferred from these findings, L. leucocephala is a good carbon sink plant. Other species also showed considerably higher carbon sequestration capacity in which they can be regarded as supportive plants enhancing the carbon sink source when combine-grown on slope.

\section{Rehabilitation of acidic slope}

Malaysia's climate is described as typical tropical with warm, high rainfall intensity as well as humidity throughout the year. As its experiences high precipitation ranging from $2000 \mathrm{~mm}$ to $2500 \mathrm{~mm}$ per annum, the highland areas especially slopes are prone to erosion and landslides [10]. Due to the high rainfall and humid climate throughout the year in Malaysia, most of the slopes are facing the acidity problem. The acidic and infertile condition of slope does not encourage the vegetation establishment and consequently the slope turns barren. The barren slope is prone to erode when rainfall dislodge soil particles and carries them off the acidic slope. It would form rills and gullies which can trigger landslides. Rainfall hitting the soil surface can also seal the soil particles and make a crust that prevents infiltration and creates runoff. 


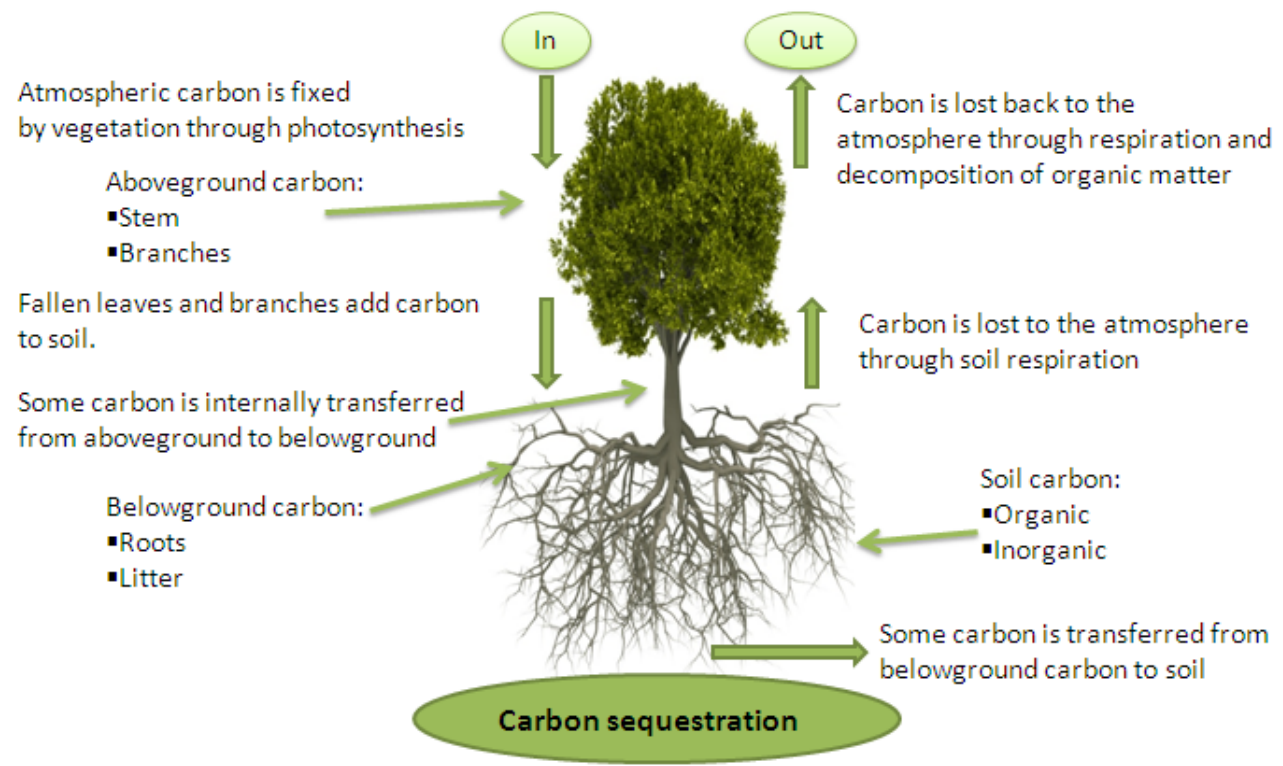

Figure 8. The process of carbon sequestration [27].

\begin{tabular}{|c|c|c|c|c|c|c|c|}
\hline \multirow{2}{*}{$\begin{array}{l}\text { Plant } \\
\text { species }\end{array}$} & \multicolumn{3}{|c|}{ Light response curves } & \multicolumn{4}{|c|}{ Carbon response curves } \\
\hline & $\begin{array}{l}\text { Amax } \\
\left(\mu \mathrm{mol} \mathrm{m} \mathrm{m}^{-2} \mathrm{~s}^{-1}\right)\end{array}$ & $\begin{array}{l}\Gamma_{1} \\
\left(\mu \mathrm{E} \mathrm{m}^{-2} \mathrm{~s}^{-1}\right)\end{array}$ & $\begin{array}{l}\text { QE } \\
\left(\mu \mathrm{E} \mathrm{m}^{-2} \mathrm{~s}^{-1}\right)\end{array}$ & $\begin{array}{l}\text { Amax } \\
\left(\mu \mathrm{mol} \mathrm{m}{ }^{-2} \mathrm{~s}^{-1}\right)\end{array}$ & $\begin{array}{l}\text { A400 } \\
\left(\mu \mathrm{mol} \mathrm{m}{ }^{-2} \mathrm{~s}^{-1}\right)\end{array}$ & $\begin{array}{l}\mathrm{gm} \\
\left(\mu \mathrm{mol} \mathrm{m} \mathrm{m}^{-2} \mathrm{~s}^{-1}\right)\end{array}$ & $\begin{array}{l}\Gamma_{\mathrm{cO} 2} \\
(\mathrm{ppm})\end{array}$ \\
\hline LL & 62 & 27 & 0.13 & 124 & 58 & 3 & 2 \\
\hline PP & 36 & 85.5 & 0.1 & 80 & 34 & 2 & 9 \\
\hline$J B$ & 12.6 & 42.8 & 0.06 & 37.6 & 16.2 & 0.11 & 70 \\
\hline LC & 9.3 & 55.9 & 0.06 & 16.7 & 10 & 0.08 & 48.5 \\
\hline TE & 4.3 & 31.0 & 0.04 & 17.7 & 2.4 & 0.08 & 96.5 \\
\hline
\end{tabular}

Maximum Assimilation Rate $\left(A_{\max }\right)$, Light Compensation point $\left(\Gamma_{1}\right)$, Quantum Efficiency $(Q E)$, Photosynthesis at ambient $\mathrm{CO}_{2}$ concentration $\left(\mathrm{A}_{400}\right)$, Mesophyll conductance $\left(\mathrm{g}_{\mathrm{m}}\right), \mathrm{CO}_{2}$ compensation point $\left(\Gamma_{\mathrm{CO} 2}\right)$, LL: Leucaena leucocephala, PP; Peltophorum pterocarpum, JB: Justicia betonica, LC: Lantana camara, TE: Thunbergia erecta

Table 3. Photosynthetic components of plants grown on slope [18]

Acid soil rehabilitation is an essential process of minimizing the acidity level of the soil and providing a better environment for plant growth. This process also will help offset greenhouse gas emissions, guarantee more food for an increasing population and contribute to the economic progress of future generations. There are several methods used in rehabilitating acidic soil. However, only three methods, which are liming, planting legumes and acid tolerant plants will be discussed in this chapter. 


\subsection{Liming}

Lime is a material that contains calcium $(\mathrm{Ca})$ or magnesium $(\mathrm{Mg})$ and will neutralize soil acidity. Carbonates are the most available and widely used liming materials. Lime decreases the acidity level of soil (increases $\mathrm{pH}$ ) by changing the hydrogen ions of soil into water and carbon dioxide $\left(\mathrm{CO}_{2}\right)$ molecule. One calcium ion $\left(\mathrm{Ca}^{++}\right)$from the lime replaces two hydrogen ions $\left(\mathrm{H}^{+}\right)$of soil complex. In addition, one carbonate ion $\left(\mathrm{CO}_{3}{ }^{2-}\right)$ reacts with water molecule $\left(\mathrm{H}_{2} \mathrm{O}\right)$ to form bicarbonate ion $\left(\mathrm{HCO}_{3}^{-}\right)$. These react with hydrogen ion $\left(\mathrm{H}^{+}\right)$to form $\mathrm{H}_{2} \mathrm{O}$ and $\mathrm{CO}_{2}$. Thus, the $\mathrm{pH}$ of soil increases due to the concentration of hydrogen ions $\left(\mathrm{H}^{+}\right)$has been reduced (Figure 9).

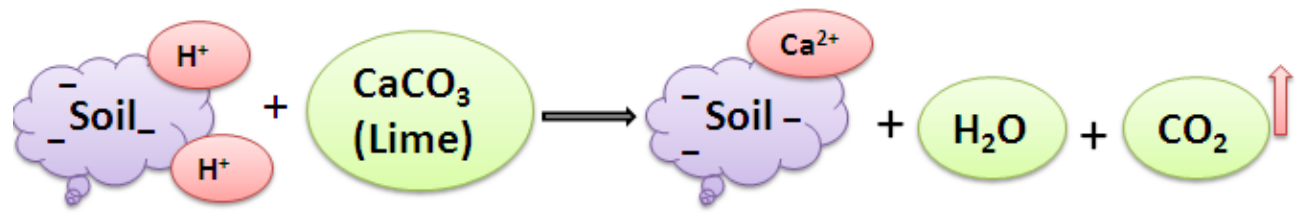

Figure 9. Reduction of soil acidity (or $\mathrm{H}^{+}$ions) by lime [28].

Regarding the mechanism of acid soil rehabilitation, liming changes the biological, structural and chemical components of soils. Organic matter decay is slow in acid soils due to the low activity levels of soil organisms. However, excessive liming rate would pollute the soil and cause environmental hazards.

\subsection{Planting legumes species}

Legumes foster production of a greater total biomass in the soil by providing additional nitrogen. Soil microbes use the increased nitrogen to break down carbon-rich residues of crops like wheat or corn. Normaniza and Barakbah [1] introduced a planting technique and documented that legumes plants showed high tolerance to acidic condition when planted with lime, rock phosphate and sphagnum moss (Figure 10). This planting technique known as "Microclimate Plant Propagation Technique" and the supplied chemicals $\left(\mathrm{CaCO}_{3}, \mathrm{~K}_{2} \mathrm{SO}_{4}\right.$ and $\mathrm{MgSO}_{4}$, and rock phosphate) assist as a suitable plant supplement to enhance the plant growth.

Another advantage of tree legumes is their deep root systems, a characteristic which confers persistence even on infertile soils [18]. Several legumes have aggressive taproots reaching six to eight feet deep and half inch in diameter that open pathways deep into the soil. Legumes contribute to an increased diversity of soil flora and fauna lending a greater stability to the total life of the soil [18]. In conclusion, nitrogen-fixing abilities of legumes plants are important for alleviating soil acidity, maintaining ecosystem fertility and long-term slope stabilization.

\subsection{Planting Al-tolerant plants}

Aluminium was the major factor for slope acidity and the presence of Aluminium was unavoidable because it was a part of most clay particles. The mechanism of $\mathrm{Al}$ accumulator 
plant to alleviate soil acidity has attracted the interest of plant ecologist and physiologist as well as evolutionary biologist. In the presence of $\mathrm{Al}$, the tolerant cultivars have efficiently uptake and utilized $\mathrm{Ca}$ and $\mathrm{P}$. The susceptible (Al-sensitive) and intermediate cultivars exhibited less $\mathrm{Ca}$ and $\mathrm{P}$ uptake and utilization. The effect of $\mathrm{Al}$ on roots indicated that the nutrient solution having $\mathrm{Al}$ at a concentration below $40 \mathrm{mM}$ has stimulated root growth, increasing the size and number of central cap cells. Beyond $60 \mathrm{mM}$, root growth was strongly inhibited with cellular damage in peripheral root cap cells.

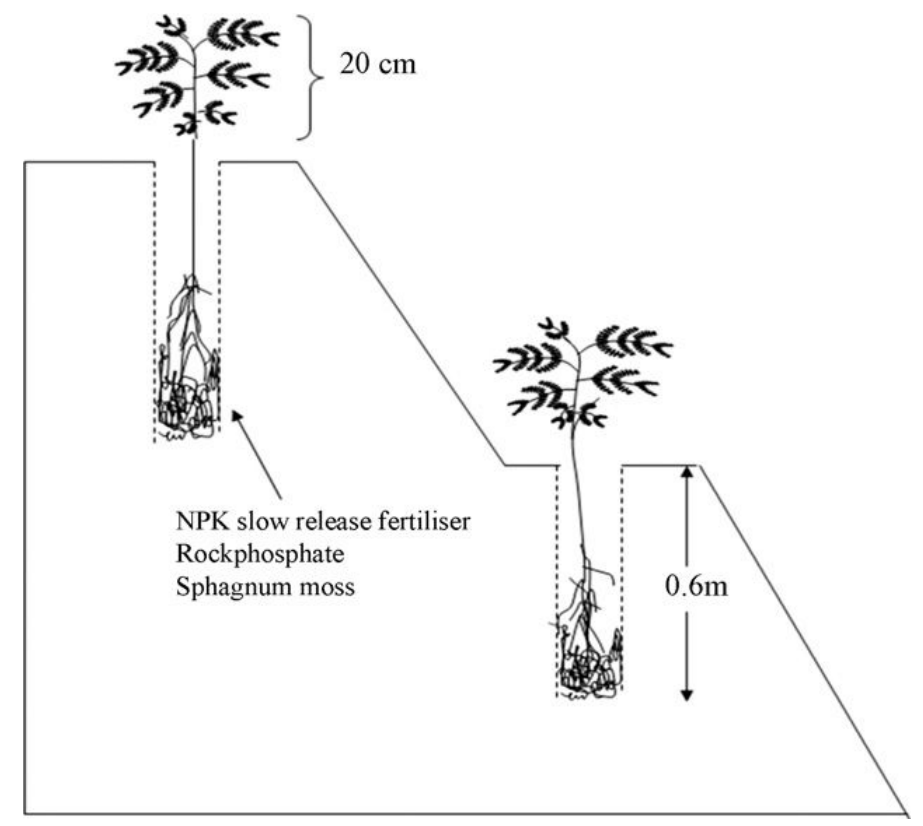

Figure 10. Plantation of legume seedling on slope [1].

Revegetation with Al-tolerant plants can be a valuable rehabilitation tool. Al-tolerant plants can tolerate and accumulate high concentrations of $\mathrm{Al}$ in the shoot whereby the growth of the plants was not affected by Al toxicity. Plants can deal with Al toxicity by setting up several aluminium tolerance mechanisms. Therefore, on such Al-contaminated soil, planting Altolerant plants plays increasingly important phytoremediation role. Proper management of these kind of plants in acidic soil may significantly contribute to restoring the natural environment. On the other hand, most of Al-tolerant plants are shrubs for example, M. malabathricum. These kind of shrubs have woody root systems ( $\mathrm{M}$ type) that give mechanical support to slopes stability. Moreover, when M. malabathricum are planted with grass, they can help to prevent sloughing of the shallow sod layer. The woody top growth also helps to stabilize rehabilitated areas by reducing surface wind velocity. These shrubs also improve soil and forest floors by drying them out, adding organic matter, and fix some nitrogen. 


\subsection{Tolerance mechanism of plants in acidic slope}

Some tolerance mechanisms to ensure its survival and growth vary amongst the species. In some cases, the plant produces small leaves as a response to acidic condition of the soil, for example smaller and thinner leaves in L. leucocephala as observed in our research (Figure 11).

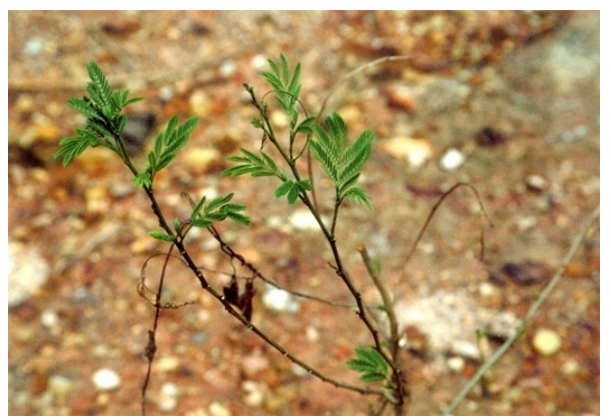

Figure 11. Leaf necrosis to reduce leaf area - a visual symptom of Aluminium toxicity, a mechanism to resist acidic condition [18].

Additionally, this visual observation indicated that plants reduced leaf number by leaf wilting and necrosis. This necrosis symptom is the sign of acid tolerance mechanism of plants, possibly as a mechanism to reduce leaf area [18]. However, high leaf chlorophyll content was observed in adapted plants in acidic soil and the plant seems to have recovered from the toxicity effect by increasing the nodulation activity. In addition, leaf analysis of acidic and non-acidic treated L. leucocephala showed that Aluminium concentration was higher by $36 \%$ in acidic treated than those in non-acidic treated L. leucocephala, implying a high Al uptake of L. leucocephala in acidic slope. The excessive accumulation of $\mathrm{Al}$ in leaf may indicate the mechanism of acidity tolerance of this species. Moreover, the plant which exhibits Al concentration in leaf more than $1000 \mathrm{ppm}$ is reportedly called an $\mathrm{Al}$ accumulator, a mechanism of $\mathrm{Al}$ adaptation of a plant to acidity (Figure 12). M. malabathricum accumulated the highest concentration of Aluminium, which was almost $1850 \mathrm{ppm}$, which makes both species an $\mathrm{Al}$ accumulator (more than $1000 \mathrm{ppm}$ ) and $A$. mangium is non-accumulator.

As similarly reported by Watanabe and Osaki [29], most of the plant samples (Evodia latifolia and Justicia betonica) exhibited general symptoms of $\mathrm{Al}$ toxicity which includes curly young leaves, reduced leaf number and necrosis, as mechanisms to reduce leaf area.

In relation to the $\mathrm{Al}$ concentration of the leaf, the soil $\mathrm{pH}$ grown with $M$. malabathricum increased up to 6.0, meanwhile 5.5 and 5.1 for L. leucocephala and A. mangium, respectively (Figure 13). The results imply a positive relationship between the concentration of $\mathrm{Al}$ in the leaf and soil $\mathrm{pH}$; as the Aluminium accumulation in leaf increased, the value of soil $\mathrm{pH}$ increased as well. The experiment showed the importance role of plant as an Aluminium accumulator in rehabilitating the acidic slope. 


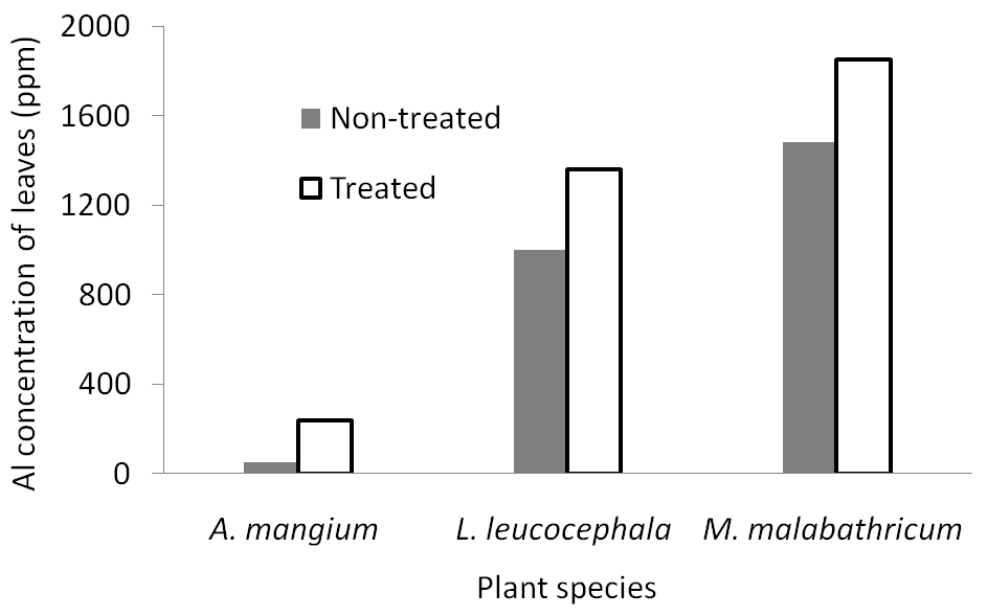

Figure 12. Al concentration of leaves of three species studied

Other possible tolerance mechanisms that could be identified in this project were increasing root length, stomatal conductance and LAI (Figure 14-17). The interaction and compilation of all tolerance mechanism contribute to the rehabilitation of the acidic soil. The photosynthetic rate and chlorophyll content of Al-tolerant plants increased with the increasing of Al concentration. Therefore, as the Al concentration increased, the tolerance mechanism has also enhanced by increasing the transpiration rate of plant.

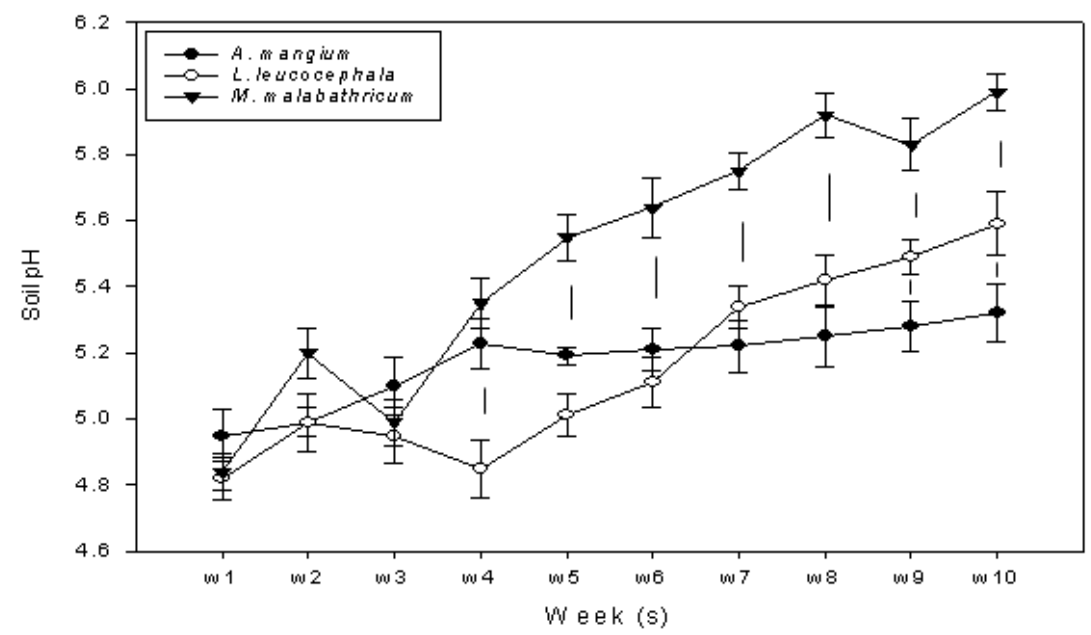

Figure 13. Soil pH changes grown by treated plants of the three species studied. 


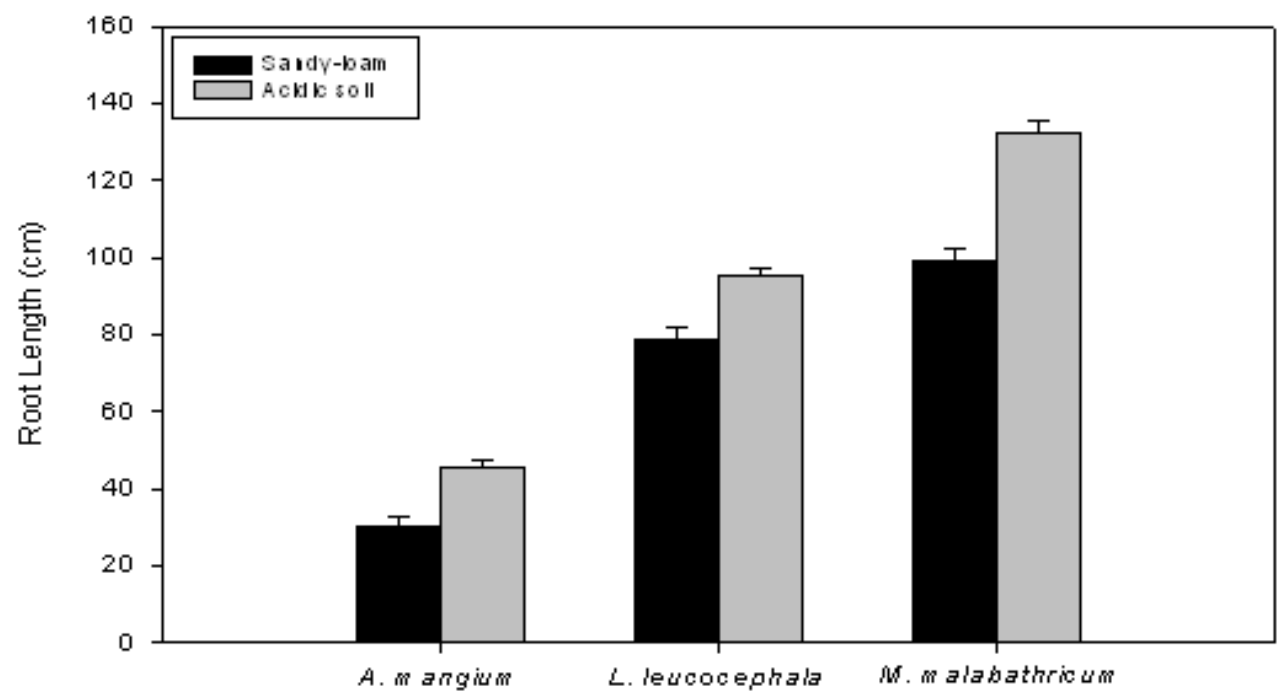

Figure 14. Root length in sandy loam and acidic soil of three species studied

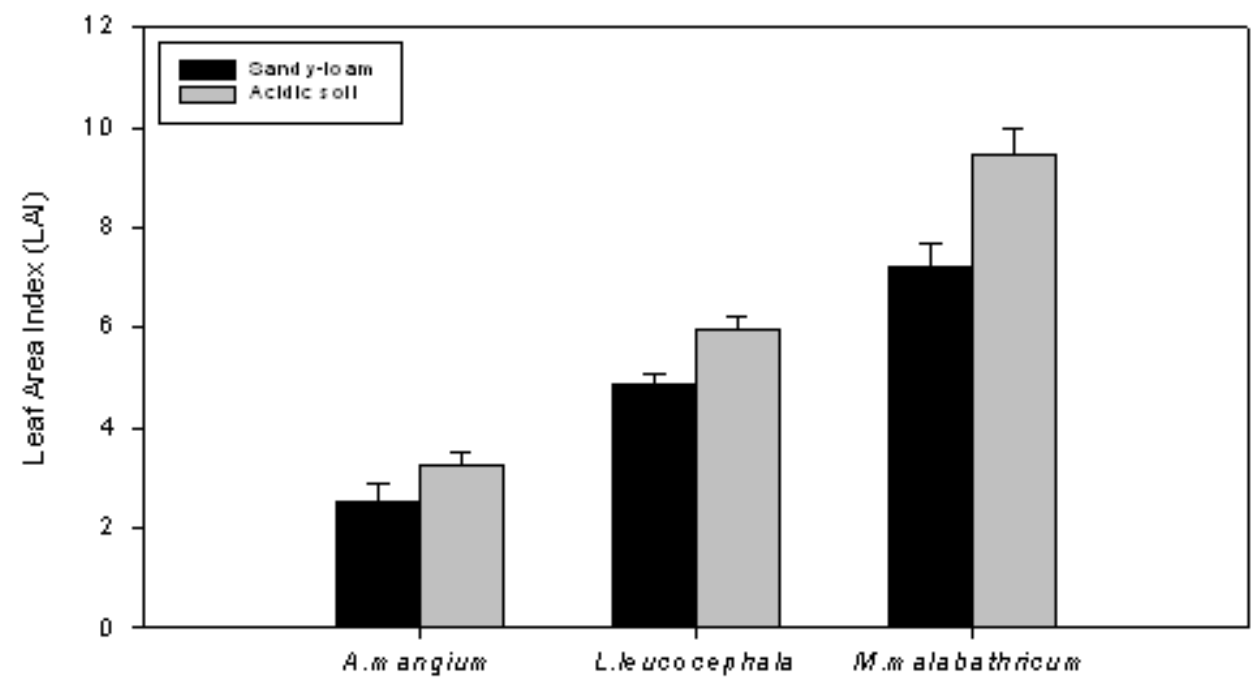

Figure 15. Leaf Area Index in sandy loam and acidic soil of three species studied 


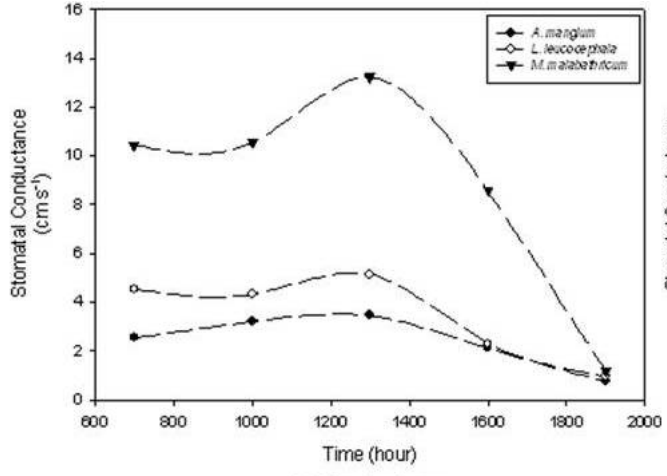

(a) Sandy-loam

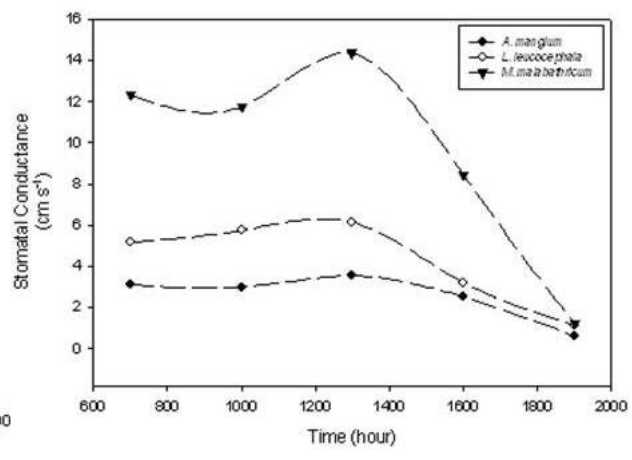

(b) Acidic soil

Figure 16. Stomatal conductance in (a) sandy loam and (b) acidic soil of three species studied

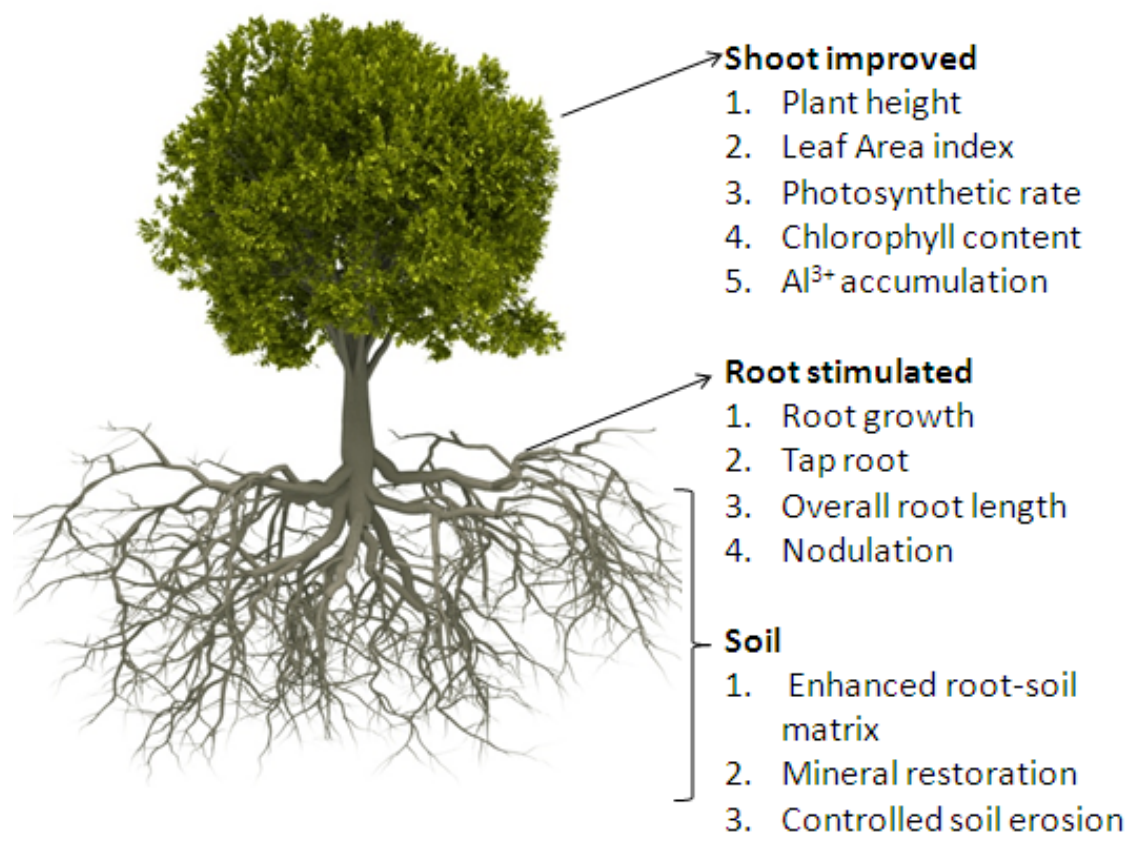

Figure 17. Tolerance mechanism of plants [30] 


\section{Potential slope plants}

Numerous studies have been conducted to determine the plant species which are suitable as slope plants. Normaniza and Barakbah [1] and Stokes et al. [31] referred that native plants usually increased the success rate of the planting program and reduced the long-term maintenance requirements. Karim and Mallik [32] suggested that the selected plants should be adapted to local climate and be able to prevent landslides or erosion. Mafian et al. [12] showed that the reinforcement of soil by vegetation is highly promising solution and this approach would be more beneficial if the species acutely possessed the mechanical (through reinforcement of soils by plant root), hydrological (through reduction in runoff and by keeping the slope relatively dry) and environmental (through the increase in carbon sequestration to counter the rising carbon dioxide level in atmosphere) aspects.

Different plant species has different hydro-mechanical characteristics and can perform different roles on slope but certain types of plants are better than others in terms of soil reinforcement and surface protection [33]. Many problems may occur after planting any type of plants which does not fulfill the slope plant characteristics. Therefore, selection of plant species by observing the potential slope plant characteristics is crucial. A set of criteria was formulated to select potential species for plantation on slope $[1,9,16,31]$. Physiological characteristics such as the high photosynthetic rate, transpiration rate and growth rate and root profiles, such as high cellulose content in roots, fine roots, root biomass, root volume and root length are considered as major criteria $[14,16]$. Additionally, the selected plant should exhibit other prominent characteristics such as good plant-water relations and tolerance of wide range of adverse condition with regard to soil acidity and water stress [9].

A list of potential tree and shrubs species was presented in Table 4. Based on the observations, L. leucocephala and P. pterocorpum showed the higher bioengineering characteristics than $A$. mangium and M. malabathricum. It was discovered that root architecture of L. leucocephala and P. pterocorpum was $\mathrm{VH}$ and $\mathrm{R}$ type, respectively. The $\mathrm{VH}$ - and $\mathrm{R}$ type root architecture was considered to be the most effective root system for slope stabilization and soil reinforcement [34]. The H-types were found to be beneficial for wind resistance. The M-types are regarded to be beneficial for controlling soil erosion. The extensive root growth and tensile strength $L$. leucocephala and P. pterocorpum were claimed to be the cause of tremendous enhancement of mechanical impacts on soil. Thus, in terms of root properties, L. leucocephala and P. pterocorpum were more prominent to play a major mechanical role on soil and their high root tensile strength would ultimately improved soil shear strength as well. These introduced tropical plants will indeed assist eco-engineer to establish bioengineering technique on slope and provide long-term soil reinforcement.

Many legumes, especially woody trees are particularly planted for controlling soil erosion, slope stabilization and restoration in tropical countries [13]. Leucaena leucoephala and Peltophorum pterocorpum, have a potential to be slope plants. L. leucoephala is one of the most productive fast growing, semi ever green and nitrogen fixing tropical legume trees. In Malaysia, $L$. 
leucocephala is used as a potential slope pioneer and wind protection. It has aggressive taproots reaching six to eight feet deep and half inch in diameter that open pathways deep into the soil (Figure 18). Nodules on the root of plant can fix atmospheric nitrogen and this is perhaps the most notable aspect that sets them apart from other plants. Additionally, P. pterocarpum is a woody ornamental plant and has a R type root system [16] (Figure 19). This tree usually is planted along roadsides, parks and slope. It has high atmospheric nitrogen-fixing potentiality.

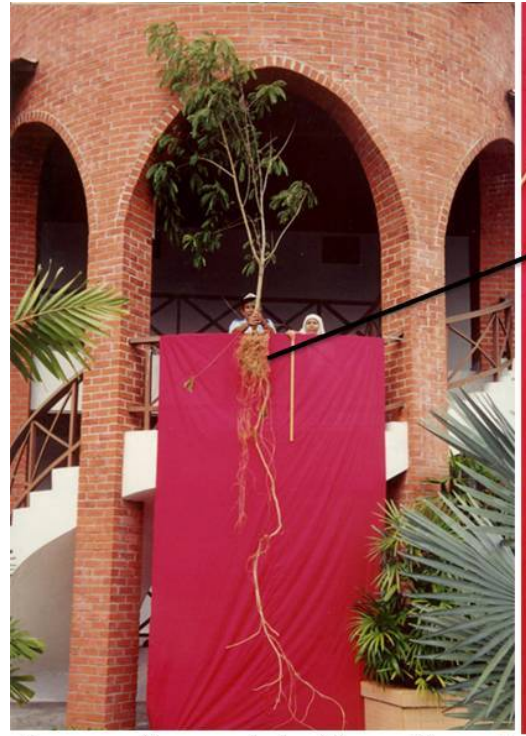

Leucaena leucocepholo - Tap rooting system

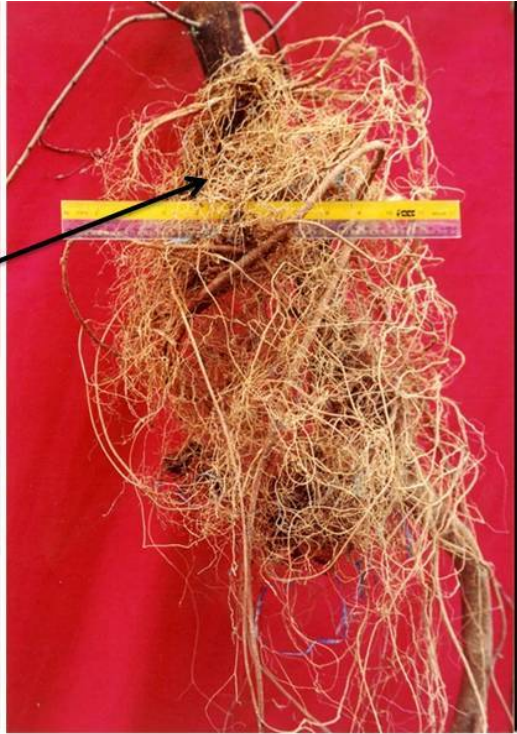

Dense fine roots

Figure 18. Root profile of a potential slope plant- Leucaena leucocephala [18].

M. malabathricum produced the $\mathrm{M}$ type root system that makes it suitable to grow at slope area (Figure 20). Acidic treated M. malabathricum showed a higher root length than non-acidic treated, implying high water absorption to perform a basic metabolic process such as photosynthesis. Plant released the absorbed water to the atmosphere by transpiring through pores on the leaves. As a result, the excessive water were removed and resulted in a drier and more stable slope. Moreover the flowering feature of M. malabathricum can help to enhance the florafauna interaction of the slopes by increasing the biodiversity. Different species have different mechanical characteristics and ranges acidic soil rehabilitation capacity. Potential slope plants and their mechanical characteristics were shown in Table 4. Additionally, a list of potential tree and shrubs species for planting in acidic slope was shown in Table 5. 

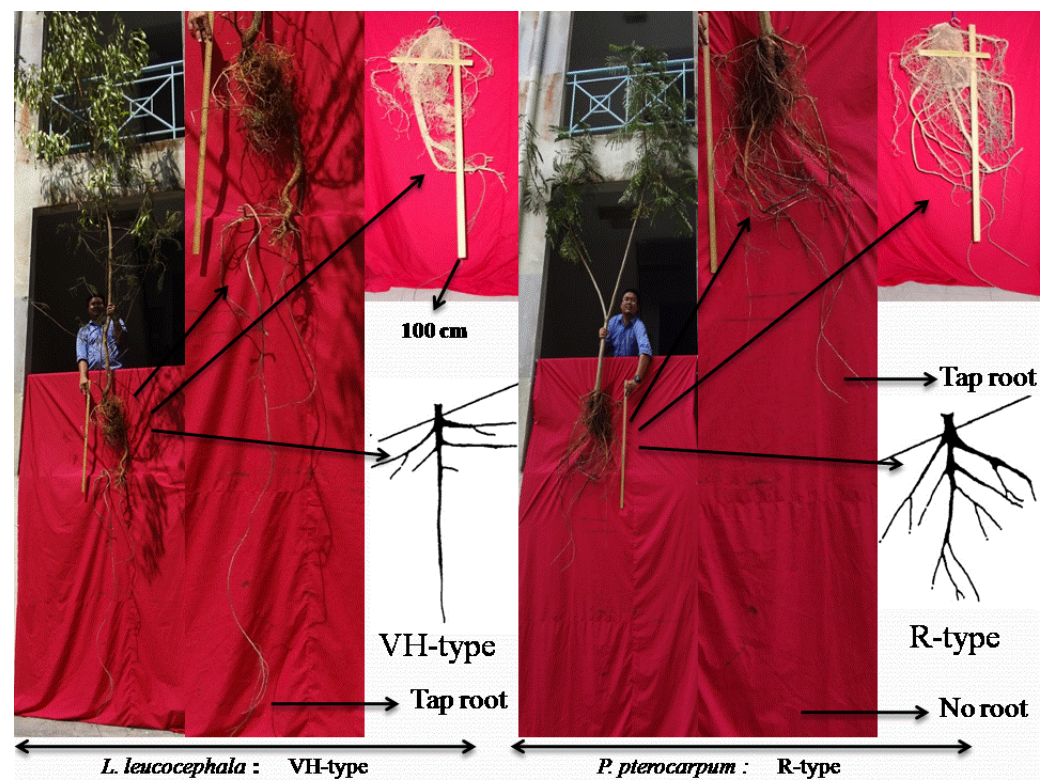

Figure 19. Potential slope plant- Peltophorum pterocarpum [16].

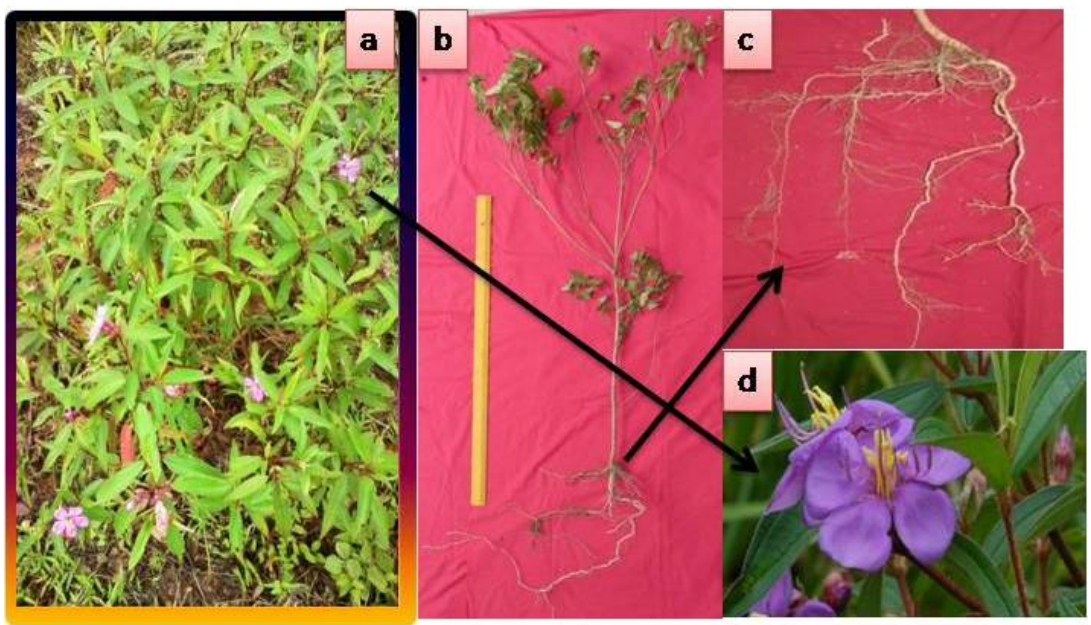

Figure 20. (a) Plant profile, (b \& c) root profile and (d) flowering feature of M. malabathricum. 


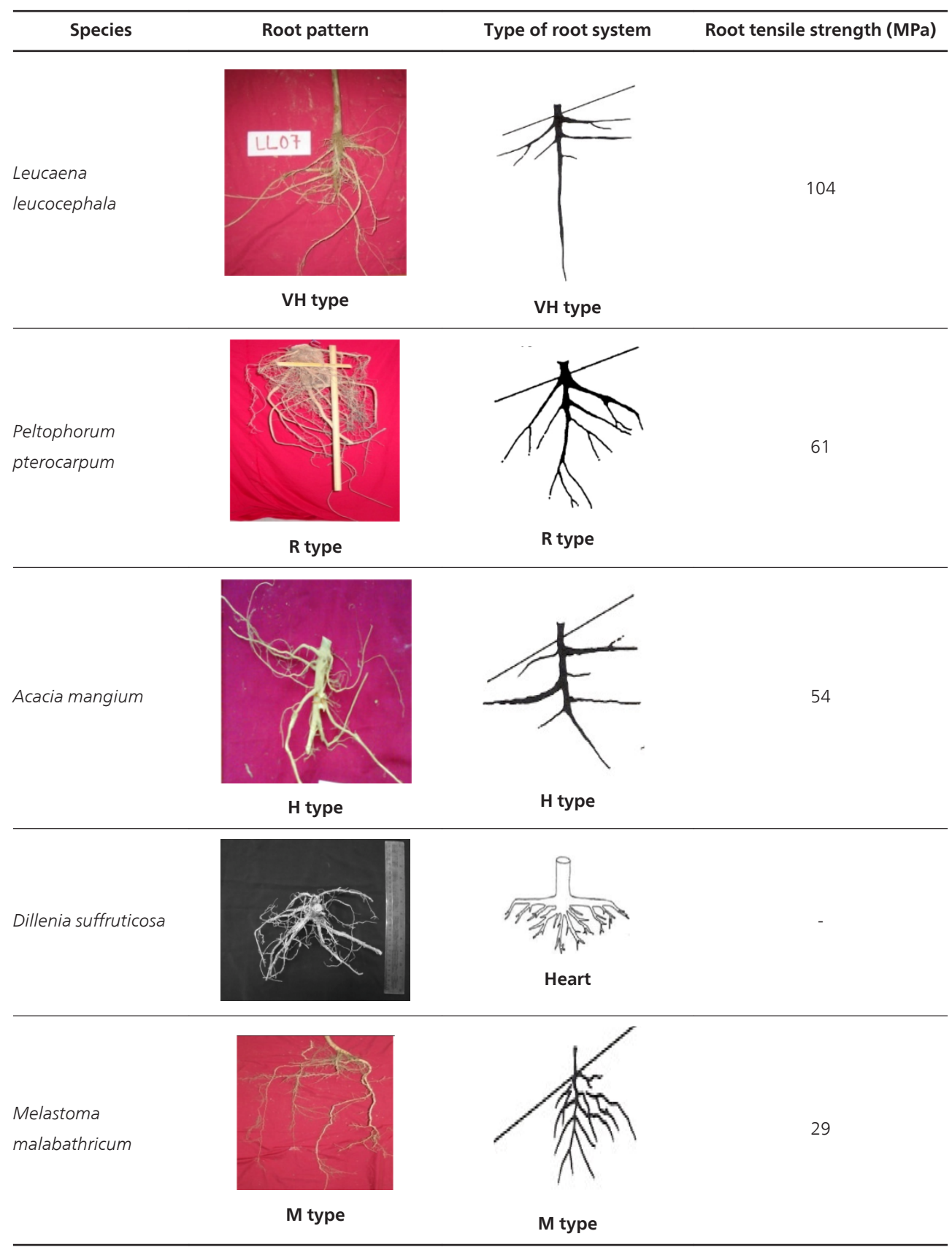

Table 4. Potential slope plants and their mechanical characteristics $[13,16,35]$. 


\begin{tabular}{lccc}
\hline \multicolumn{1}{c}{ Species } & Genus & Family & Site (soil pH) \\
\hline Bixa orellana & Baxia & Bixaceae & $>5$ \\
\hline Leucaena leucocephala & Leucaena & Mimosoideae & $>$, Moderate acidic \\
\hline Acacia mangium & Acacia & Fabaceae & $>4$, Moderate acidic \\
\hline Bauhinia purpurea & Bauhinia & Fabaceae & $>4$, Moderate acidic \\
\hline Melastoma malabathricum & Melastoma & Melastomataceae & $<3$, Severe acidic \\
\hline Thunbergia erecta & Thunbergia & Acanthaceae & $>5$ \\
\hline Justicia betonica & Justicia & Acanthaceae & $>5$ \\
\hline Lantana camara & Lantana & Verbenaceae & $>5$ \\
\hline Hibiscus mutabilis & Hibiscus & Malvaceae & $>5$ \\
\hline Vetiver zizanioides & Chrysopogon & Poaceae & $>5$ \\
\hline
\end{tabular}

Table 5. List of species for planting in acidic slope and classified by slope characteristic $[13,18]$.

\section{General discussion}

The observation of this study provides the key findings and contribution of tropical plants to alleviate soil acidity and soil erosion. The bioengineering characteristics of selected tropical plants have been intensively assessed to identify their potentiality towards slope stabilization. This observation also revealed the contribution of pioneer species to enhance the process of natural succession on slope. Amongst the tropical plants, few were suitable for reinforcing slope and rehabilitation of acidic slope, exhibiting tolerance mechanism in soil acidic condition. Based on the field studies, significant morphological and physiological changes were observed in M. malabathricum in response to severe acidic $(<3)$ condition. These changes include the improved photosynthetic rate, transpiration rate, LAI and root system. In addition, the highest concentration of $\mathrm{Al}$ (> $1200 \mathrm{ppm}$ ) in the M. malabathricum leaves, either Al-treated or not, has made this species the most suitable plant for severe acidic slope. This study also reveals an alternative approach to alleviate the acidity. Besides liming, legume trees were recommended for acidic slope rehabilitation due to their nitrogen-fixing abilities and extensive root systems that can penetrate a deeper soil depth. The deeper the soil depth, the higher the soil $\mathrm{pH}$ (less acidic), which makes this condition more conducive for the root establishment as well as the plant growth as a whole [18].

In terms of the alleviation of soil erosion, the soil reinforcement of slope stability is mainly depending on the properties of root systems of plant species. Root biomass, root architecture and tensile strength were remarked as prominent engineering properties of plants to assess its potentiality for soil reinforcement [13]. The extensive root growth and development of the taproot (VH-type) of L. leucocephala has resulted in a tremendous enhancement of mechanical effects on soil. As inferred from these findings, M-type root was suitable in protecting ground 
cover from surficial erosion. In relations to this mechanical aspect, plant density also showed an important contribution for controlling soil erosion. Research findings exhibited that higher plant density would reduce the soil erosion rate, indicating a high soil-root interaction and canopy interception. Apart from that, carbon sink potentiality of plants was also measured via photosynthetic components of plants grown on slope. It can be envisaged that the outstanding carbon sink potential of the slope plant community would confer numerous advantages, not only to improve the global warming and sustain the ecosystem but also to produce more stable and safe slopes.

\section{Conclusion}

The new information and findings presented in this chapter have mostly been achieved through the bioengineering research, carried out in Malaysia. Aluminium accumulating plants and new potential tropical slope plants are introduced and recommended for the revegetation programme of the slope to alleviate soil acidity and erosion. These potential tropical plants' attributions will be beneficial for enlisting database which can be further applied for ground bio-engineering techniques in other tropical countries in the South-East Asia. It is our earnest hope that the new discoveries and the outcomes of this knowledge would benefit the soil science as well as other related disciplines.

\section{Acknowledgements}

The authors would like to thank University of Malaya (UMRG-RG042-09SUS, RG120-11SUS, RG019-09AET, PV084-2012A, PV052-2011A), Slope Engineering Branch of Public Works Department Malaysia, Ministry of Science, Technology and Innovation (SF16-02-03-6013) and Ministry of Higher Education (FP070-2010A) for the research grants throughout this project.

\section{Author details}

Normaniza Osman*, Mohammed Saifuddin and Aimee Halim

*Address all correspondence to: normaniza@um.edu.my

Institute of Biological Sciences, Faculty of Science, University of Malaya, Kuala Lumpur, Malaysia 


\section{References}

[1] Normaniza O. Barakbah SS. The effect of plant succession on slope stability. Ecological Engineering 2011;37 139-147.

[2] Chau KT. Sze YL. Fung MK. Wong WY. Fong EL. Chan LCP. Landslide hazard analysis for Hong Kong using landslide inventory and GIS. Computers and Geosciences 2004;30 429-443.

[3] Dong JJ. Tu CH. Lee WR. Jheng YJ. Effects of hydraulic conductivity/strength anisotropy on the stability of stratified, poorly cemented rock slopes. Computers and Geotechnics 2012;40 147-159.

[4] Mizal-Azzmi N. Mohd-Noor N. Jamaludin N. Geotechnical Approaches for Slope Stabilization in Residential Area. Procedia Engineering, 2011;20 474-482.

[5] Rajakumar P. Sanjeevi S. Jayaseelan S. Isakkipandian G. Edwin M. Balaji P. Ehanthalingam G. Landslide susceptibility mapping in a hilly terrain using remote sensing and GIS. Journal of the Indian Society of Remote Sensing 2007;35 31-42.

[6] Mugagga F. Kakembo V. Buyinza M. A characterisation of the physical properties of soil and the implications for landslide occurrence on the slopes of Mount Elgon, Eastern Uganda. Natural Hazards 2012;60 1113-1131.

[7] Song W. Yongguo Z. Xiaoxu G. Xiaoning L. Slope Landscape Classification and Application Security in the Special Section of Western. Procedia Environmental Sciences Part A 2012a;12 146-151.

[8] Song YS. Hong WP. Woo KS. Behavior and analysis of stabilizing piles installed in a cut slope during heavy rainfall. Engineering Geology 2012;129-130 56-67.

[9] Normaniza O. Barakbah SS. Parameters to predict slope stability-Soil water and root profiles. Ecological Engineering 2006;28 90-95.

[10] Huat BBK. Kazemian S. Study of Root Theories in green tropical slope stability. Electronic Journal Of Geotechnical Engineering 2010;15 1825-1834.

[11] Stokes A. Ghani MA. Salin F. Danjon F. Jeannin H. Berthier S. Kokutse AD. Frochot $\mathrm{H}$. Root morphology and strain distribution during tree failure on mountain slopes Eco-and Ground Bio-Engineering: The Use of Vegetation to Improve Slope Stability. In: Stokes, A., Spanos, I., Norris, J. E. \& Cammeraat, E. (eds.). Springer Netherlands; 2007.

[12] Mafian S. Huat BBK. Rahman NA. Sing H. Potential plant species for live pole application in tropical environment. American Journal of Environmental sciences 2009;5 759-764.

[13] Nordin MA. Osman N. Abdullah CH. Pull-out and tensile strength properties of two selected tropical trees. Sains Malaysiana 2011;40 577-585. 
[14] Normaniza O. Faisal HA. Barakbah SS. Engineering properties of Leucaena leucocephala for prevention of slope failure. Ecological Engineering 2008;32 215-221.

[15] Fattet M. Fu Y. Ghestem M. Ma W. Foulonneau M. Nespoulous J. Le Bissonnais Y. Stokes A. Effects of vegetation type on soil resistance to erosion: Relationship between aggregate stability and shear strength. Catena 2011;87 60-69.

[16] Saifuddin M. Normaniza O. Physiological and root profile studies of four legume tree species. Life Science Journal 2012;9 1509-1518.

[17] Stokes A. Mattheck C. Variation of wood strength in tree roots. Journal of Experimental Botany 1996;47 693-699.

[18] Normaniza, O., Barakbah, S.S. and Faisal, H.A. 2009. The contribution of plant community to accelerate the process of natural succession. American Journal of Environmental Sciences. 5 (1): 7-15.

[19] Evette A. Labonne S. Rey F. Liebault F. Jancke O. Girel J. History of bioengineering techniques for erosion control in rivers in western Europe. Environmental Management 2009;43 972-984.

[20] Preti F. Giadrossich F. Root reinforcement and slope bioengineering stabilization by Spanish Broom (Spartium junceum L.). Hydrology and Earth System Sciences 2009;13 1713-1726.

[21] Toriman ME. Shukor MN. An analysis of rainfall interception on the selected experimental plot of Pangkor Hill Reserved Forest. Journal Wildlife and National Park $2006 ; 169-178$.

[22] Mahdavi K. Choupanian A. Gheytouri M. Mahdavi M. Effect of physiographic factors on soil carbon sequestration in Kermanshah (Iran). International Journal of Forest Soil and Erosion 2012;2 159-162.

[23] Gyssels G. Poesen J. The importance of plant root characteristics in controlling concentrated flow erosion rates. Earth Surface Processes and Landforms 2003;28 371384.

[24] Kidd PS. Proctor J. Effects of Aluminum on the growth and mineral composition of Betulapendula Roth. Journal of Experimental Botany 2000;51 1057-1066.

[25] Raven JA. Karley AJ. Carbon Sequestration: Photosynthesis and Subsequent Processes. Current Biology 2006;6 R165-R167.

[26] Malhi Y. Grace J. Tropical forests and atmospheric carbon dioxide. Trends in Ecology \& Evolution 2000;15 332-337.

[27] Lal R. Soil carbon sequestration to mitigate climate change. Geoderma 2004;123 1-22.

[28] Meiwes KJ. Application of lime and wood ash to decrease acidification of forest soils. Water, Air, and Soil Pollution 1995;85 143-152. 
[29] Watanabe T. Osaki M. Mechanisms of adaptation to high aluminum condition in native plant species growing in acid soils: A review. Communications in Soil Science and Plant Analysis 2002;33 1247-1260.

[30] Idris RM. Rehabilitation of acidic soil using potential slope plants. M.Sc Thesis, University of Malaya; 2011.

[31] Stokes A. Atger C. Bengough A. Fourcaud T. Sidle R. Desirable plant root traits for protecting natural and engineered slopes against landslides. Plant and Soil 2009;324 $1-30$.

[32] Karim MN. Mallik, AU. Roadside revegetation by native plants: I. Roadside microhabitats, floristic zonation and species traits. Ecological Engineering 2008;32 222-237.

[33] Coppin NJ. Richards IG. Use of Vegetation in Civil Engineering, Construction Industry Research \& Information Association, 2007.

[34] Reubens B. Poesen J. Danjon F. Geudens G. Muys B. The role of fine and coarse roots in shallow slope stability and soil erosion control with a focus on root system architecture: a review. Trees - Structure and Function 2007;21 385-402.

[35] Yen CP. Tree root patterns and erosion control. In: Jantawat, S. (Ed.), Proceedings of the international workshop on soil erosion and its countermeasures. Soil and Water Conservation Society of Thailand, Bangkok, 1987; 92-111. 
